\title{
"TRANSLANGUAGING" AS A SOCIALLY JUST PEDAGOGY
}

\author{
Ellen Hurst
}

University of Cape Town

ellen.hurst@uct.ac.za

\author{
Msakha Mona \\ University of Cape Town \\ Msakha.Mona@uct.ac.za
}

\section{ABSTRACT}

South African higher education relies primarily on English as the medium of education. This is a result of the colonial history of the country, yet it disadvantages a large section of South African students who undertake their education in a language that is not their first language. It also reproduces the monolingual norm and anglonormativity. This can be read as a social justice issue, since students are impacted negatively by discrimination through language. Indeed, recent protest movements, particularly Rhodes Must Fall, have highlighted language as a critical issue in the "decolonisation" of the university curriculum. This article presents translanguaging pedagogy as a way to address this issue; it analyses the implementation of translanguaging pedagogies in an introductory course at the University of Cape Town in 2015 and 2016. Through an analysis of lecturer reflections, classroom practice and assessments, it highlights how translanguaging pedagogies can empower students who are disempowered by English monolingualism and it demonstrates how students respond positively to these pedagogies. The article makes the argument that multilingual pedagogies are a necessary response to the current crisis in South African higher education.

Keywords: translanguaging; multilingualism; decolonisation; higher education

\section{UNISA

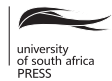

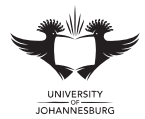

Education as Change

Volume 21 | Number 2 | 2017 | pp. 126-148

www.educationaschange.co.za https://doi.org/10.17159/1947-9417/2017/2015

ISSN 1947-9417 (Online), ISSN 1682-3206 (Print)

(C) The Author(s) 2017 


\section{INTRODUCTION: THE SOUTH AFRICAN CONTEXT AND THE COLONIAL WOUND}

South Africa is a highly multilingual country, with 11 official languages and numerous other languages spoken as first or home languages and learned in the early years of schooling. However, from Grade 3 onwards education is dominated by the English language, a result of the colonial history of the country and its education system. This situation is intensified by the current dominance of English in higher education worldwide. As a result, universities around the country such as the University of Cape Town use the English language as the medium of instruction.

There are a number of problems attached to this dominance of English, the most important of which is that not all young South Africans have equal access to English in their schools, leading to a situation in which some students are unable to attend university due to their limited access to English. Other students may be accepted into university, yet with a more limited proficiency than their peers, which can result in lower confidence and participation, and ultimately lower grades and success rates in their chosen degrees. This results in what has been described by Fanon (1952) as the "colonial wound," which Mignolo $(2009,3)$ describes as the damage done by "the fact that regions and people around the world have been classified as underdeveloped economically and mentally."

Fanon (1952) argued that "the wretched of the earth" (les damnés de la terre) are dehumanised by the process of colonisation, particularly through the use of the language of the colonisers. Mignolo $(2005,8)$, developing Fanon's ideas, explains that:

Coloniality names the experiences and views of the world and history of those whom Fanon called les damnés de la terre ("the wretched of the earth," those who have been, and continue to be, subjected to the standards of modernity). The wretched are defined by the colonial wound, and the colonial wound, physical and/or psychological, is a consequence of racism, the hegemonic discourse that questions the humanity of all those who do not belong to the locus of enunciation (and the geo-politics of knowledge) of those who assign the standards of classification and assign to themselves the right to classify. The blindness toward histories and experiences lying outside the local history of Western Christianity, as shown by secular Europeans, grounded in the Greek and Latin languages, and unfolded in the six vernacular imperial languages (Italian, Spanish, Portuguese, French, German, and English), has been and continues to be a trademark of intellectual history and its ethical, political, and economic consequences.

Decolonial thought seeks to re-inscribe what Mignolo calls "border thinking"- "the work of theorists and social movements connected to the wretched" (Kerner 2014, 149) - as a legitimate epistemic position, and to challenge the dominance of the Eurocentrist modernist view of the world (although the discourse of decolonisation has itself been critiqued for its lack of a clear identification of "colonial" thought and the tendency to replace Euro-centrism with other-centrisms). Decolonisation ultimately also involves 
a rejection of dominant European languages and the reinforcement of languages that have been negated by colonial modernity.

In Hurst (2016) evidence of the colonial wound emerged from students' language histories (or language biographies) in a course based in the humanities faculty at the University of Cape Town. For example, using African languages at school was seen as a "disadvantage"; students described effects on their confidence resulting from their experiences navigating language and education. Other students described shyness, especially when speaking in class, and their contrasting confidence speaking in their home language. English had the power to silence students, through the fear that they would say something wrong and be laughed at by other students. Respondents also mentioned feelings of sadness relating to the loss of their home languages, and their struggles speaking English. Other emotions that emerge from the data in Hurst (2016) were fear, anger and resentment. Most tellingly, in terms of Mignolo's definition of the colonial wound, students described how the emphasis on English made them doubt their own intelligence, as their home languages were seen as inferior. This clearly speaks to the concept of the "colonial wound" as it shows the ways in which people on the border are positioned as inferior to the centre, both in terms of language and social practice.

McKinney (2017) critiqued the monolingual norm in South African education, particularly the "anglonormativity" of the higher education sector, the notion of languages as pure, autonomous and bounded entities. She argues that, in international scholarship, "Language is currently understood as a socially, culturally, politically and historically situated set of resources (Blommaert and Rampton 2011; Heller 2007) and as part of a multi-modal repertoire that is used in meaning-making" (McKinney $2017,2)$. This theoretical turn towards language as resource and practice has led to theories such as superdiversity (Blommaert and Rampton 2011) and translanguaging (Canagarajah 2013) which challenge assumptions around the monolingual norm-the idea of one nation, one language, which is critiqued as a product of European nation state building (cf. Makoni and Pennycook 2005). This article takes the theoretical approach that multilingualism is the norm in South Africa, not monolingualism, and works with a pedagogic approach that problematises the notion of discrete homogenous languages and "standard language" in the South African context. The language context of South Africa, and the Western Cape where this study is located, is a complicated one and ties to the social and political history of the country.

\section{OVERVIEW OF SOUTH AFRICAN AND WESTERN CAPE LANGUAGES}

The South African context involves 11 official languages (Afrikaans, English, Ndebele, sePedi/Northern Sotho, Sotho, Swazi, Tsonga, Tswana, Venda, isiXhosa and isiZulu) as well as numerous unofficial languages. Other than English and Afrikaans, the official languages tend to be geographically distributed according to pre-colonial distribution 
of speakers. English is used throughout the country as a medium of education, so its distribution is more widespread, although there is less access to English in schools in less advantaged areas such as peri-urban townships and rural areas. This means that English proficiency tends to link to financial status or class, as well as "race." White people in South Africa predominantly speak either English or Afrikaans. Afrikaans is also nationally distributed due to the influence of the Afrikaans government prior to and during apartheid. However, Afrikaans is most dominant in the western part of the country. In the Western Cape, where the University of Cape Town is located, the three dominant languages are English, Afrikaans and isiXhosa. IsiXhosa is a language in the Bantu Nguni cluster, and it was historically distributed throughout the Eastern Cape and parts of the Western Cape. Migration patterns since the mid-18th century have brought many isiXhosa speakers to Cape Town. Afrikaans in the Cape is predominantly spoken by people who classify or are classified as "Coloured." The Coloured identity emerged from the 17th century onwards and involves a complex heritage including indigenous Khoisan, slaves from the Dutch East Indies, Europeans and Africans (such as the Xhosa) (Adhikari 2005, 2). The Coloured identity group primarily speaks Afrikaans as a result of the role of the Dutch in the colonial history of the country, and today, many Coloured people are bilingual in English and Afrikaans. The Afrikaans spoken by many Coloured people in the Cape Town region is a dialect referred to as Kaapse taal (Cape language).

Within the higher education context, English is the medium of instruction in nearly all South African universities. This is a legacy of the rejection of Afrikaans as a medium of instruction during the apartheid struggle, as well as the role of English speaking Europeans in the colonial history of the country. English is sustained today in South African education and especially higher education, partly due to its global status. However, the dominance of English in South African higher education is increasingly under examination due to the role it plays in reproducing disadvantage, and its link to what is considered a colonial European epistemology.

\section{RHODES MUST FALL-BACKGROUND AND MOTIVATIONS}

The Rhodes Must Fall (RMF) movement, ${ }^{1}$ formed at the University of Cape Town in 2015, ostensibly aimed to remove the statue of Cecil Rhodes ${ }^{2}$ from the university campus. However, the movement was symbolic and metaphoric in that the call by activists to remove the statue was not the end in itself, but rather was seen by the movement as a beginning of the decolonising process at UCT. Part of the work that

1 The RMF movement led to the linked Fees Must Fall (FMF) movement, which primarily called for economic access through free education.

2 Cecil Rhodes was a British businessman, imperialist, and prime minister of the Cape Colony in the late 1800s, who annexed large areas of land in Southern Africa. He bequeathed the land on which the University of Cape Town is built. 
the movement is still engaged in entails dealing with the "Rhodes that is lodged in our ways of thinking, in our curricular and pedagogical practices" (Garuba 2015). Rhodes therefore symbolically highlighted colonial effects that are a daily experience for UCT students.

The statue was seen as a reminder of the fact that UCT was not initially designed for people of colour. Critiques levelled against the monument included the sense that despite the university's knowledge of Rhodes's views about white European superiority, and its stated commitment to transformation and redress, it retained in the Rhodes statue a symbol that reminded people of colour about their "inferiority" and historical rejection from UCT. In an open letter to UCT's vice chancellor, the former Students' Representative Council president wrote (Mahapa 2014):

The institutional culture of those former model $\mathrm{C}$ schools $^{3}$ is still such that it subjugates the talents, self-esteem and self-image of the Black and Coloured learners. More like UCT, having a statue of Cecil John Rhodes, how am I supposed to perceive myself and what is recorded in my subconscious mind each day passing a statue of someone whose modus operandi was cynical crass inhumane exploitation of Africans? He out-rightly and proudly believed that those of my pigmentation are not part of the human race and are not capable of thriving in academia.

What Mahapa is referring to, and what RMF is challenging, is what Fanon would call "petrification," where students of colour are forced into a "zone of nonbeing" (Fanon 1976, 8 in Gibson 2011, 76). Language is one of the ways through which petrification is administered. Students of colour whose first language is not English, are forced through South African educational policies to divorce themselves from their home languages, and to assimilate to English for academic participation. This can undermine knowledge reproduced through African languages: "It is in these languages, spoken by at least 90 per cent of us, that our histories, cultures, and indigenous knowledge rest" (Prah 1999, 39). The use of a European language as the (monolingual) medium of instruction and a European higher education institutional culture and curriculum (knowledge) can therefore be seen as unjust as it reproduces notions of the superiority of Western knowledge and language, resulting in the colonial wound as described above, and is inappropriate within a highly multilingual African university. As Breidlid suggests,

when the thinking and acting of the majority of the people in a country, that is, their cultural expression, is more or less excluded from the curriculum ... it does something profoundly damaging to the self-confidence and self-esteem of those people, aside from the obvious learning challenges it creates in school. (Breidlid 2013, 65-6)

While the RMF movement therefore stands for justice and problematises valid issues, there has hardly been a solid consensus as to what a decolonised university, curriculum or pedagogy would look like. Debates were held in RMF plenaries in 2015-2016 where

3 Model C schools were schools reserved for children classified as white in apartheid South Africa. They were opened to all racial classifications in the early 1990s. 
participants tried to make suggestions regarding curriculum reform. In the absence of one unified stance about what decolonisation means, there were some issues that attracted consensus, notably the inclusion of indigenous knowledges and the use of other local languages in the academy. The "decolonisation" of the existing Western and monolingual education system will inevitably need to involve addressing the language problem.

Given that the South African constitution recognises the 11 official languages as equally important, and considering the earlier discussions regarding the monolingual norm and the multilingualism of many South African learners, it becomes clear that a "decolonial" curriculum and pedagogy would need to be a multilingual one.

\section{SOCIAL JUSTICE}

This article proposes that a multilingual pedagogical approach is a socially just response to calls for decolonial education in South Africa. Social justice is "interpreted as social and civic responsibilities, commitment to promoting the common good, and participation in democratic processes and cultural diversity" (Cumming-Potvin 2009, 84). A social justice approach includes "investigating barriers to students' learning outcomes and using teaching and assessment strategies fairly." Students within a socially just pedagogic framework should not be impacted negatively by "discrimination through sex, language, culture, ethnicity, religion or disability (or socio-economic status and geographic location)" (84).

Fraser's (1997) framework highlighted the need for both redistribution and recognition (social equality and the recognition of difference) to achieve social justice; while North (2006), using this framework, suggests "a shift from justice for redistribution to justice for recognition," in other words putting a focus on socio-cultural groups who are struggling to "defend their identities, end cultural domination and win recognition" (Cumming-Potvin 2009, 84). This framework, when applied to language, also links to the notion of "linguistic human rights":

There is a growing literature that looks at language policies from a human-rights approach (Babaci-Wilhite and Geo-JaJa, 2011; Babaci-Wilhite, 2012 and 2013; Bostad, 2012; SkutnabbKangas, 1994 and 2000; Sure and Ogechi, 2009). This perspective is based on the premise that the use of a familiar language in education should be regarded as a right. (Gyagenda and RajabGyagenda 2014, 149)

According to Gyagenda and Rajab-Gyagenda $(2014,159)$ African countries that have chosen English or French as mediums of instruction have failed to develop "a viable and appropriate language of instruction policy that engenders a sense of self, identity, and empowerment. Education must liberate and empower and not subjugate nor disempower." This notion of social justice can therefore be tied to calls for decolonisation through the use of appropriate multilingual pedagogy. 


\section{A SOCIALLY JUST APPROACH: TRANSLANGUAGING}

A socially just approach involves critical questioning and resistance, analysis of systems of oppression and positioning, and encouraging social action and practising democracy. This article takes as data a course in the humanities faculty at the University of Cape Town which applies an explicit critique of the hegemony of English in South African academic spaces and encourages linguistic activism through enabling other languages. The course first problematises monolingual and anglo-normativity, then brings into focus other dominant discourses - heteronormativity, racism, sexism and so on, and ultimately provides students with tools to critique these dominant discourses through discourse analysis (although of course, discourse analysis itself arises from the hegemonic European academic tradition).

The pedagogic approach adopted by the course involves "translanguaging." Translanguaging is a term first coined by Williams (1994) meaning "the ability of multilingual speakers to shuttle between languages, treating the diverse languages that form their repertoire as an integrated system" (Canagarajah 2011, 401). The translanguaging pedagogic approach is in response to the language practices of the students, which include many dialects, accents, and high levels of multilingualism. Rather than simply trying to enforce multilingualism by having separate classrooms teaching in "pure" isiXhosa or isiZulu — a strategy that merely reinforces monoglot ideologies through the assumption that there can be multiple monolingualismstranslingual practice (as described by Canagarajah [2013]) is more messy and complex. It assumes that language practices involve complex communicative strategies including for example crossing, code-meshing, polyglot dialogue, plurilingualism etc.

Translanguaging pedagogies can include strategies such as encouraging students to cross between all known languages in multilingual classroom contexts (Makalela 2015), using code-meshing varieties and languages in essay writing (Canagarajah 2013), and developing "concept glossaries" which stage the development of terms in African languages through translingual discussions (Madiba 2014).

According to Makelela $(2015,21)$, studies on translanguaging posit that "using a large linguistic repertoire at the students' disposal is important for identity formation, that is, the choice on who one is and who one becomes. Instead of separating the self and the other, translanguaging gives room for both and legitimises their interrelationship to advancing acquisition of new knowledge." Makelela furthermore suggests that translanguaging can be seen as a decolonial move:

[the] fuzziness and blurring of boundaries between languages in the translanguaging classes are (i) necessary and relevant features of the 21 st century to enhance epistemic access for speakers in complex multilingual spaces, and ... are (ii) indexical to the pre-colonial African value system of ubuntu. (Makelela 2015, 15)

Makelela refers to this "complex interdependence of language systems as ubuntu translanguaging to signal an ancient African value system of human, cultural and 
linguistic interconnectedness" (Makalela 2015, 21) which disrupts the traditional classroom environment that treats languages as sealed units, capable of being categorised. Importantly, translanguaging does not exclude colonial European languages that have also been part of the picture of contact in Africa, so it is consistent with the entangled nature of coloniality.

\section{METHODS: IMPLEMENTING TRANSLANGUAGING PEDAGOGIES}

The data for this article come from a number of translanguaging pedagogies implemented in "Texts in the Humanities," a first year level course for students on the extended degrees in the humanities faculty at the University of Cape Town.

The extended degrees in the humanities faculty at the University of Cape Town are four-year degrees, rather than the standard three-year humanities degrees, and they are part of an "access programme" intended to provide support for students from government-designated demographic groups who enter the humanities faculty with lower points than three-year degree students. The purpose of the programme is to redress historical and ongoing inequalities which lead to greater participation and success in higher education of white students. For this reason, at UCT extended degree students are almost exclusively black African or Coloured students. White students are not part of the programme due to government funding restrictions. This leads to some stigma around the programme, yet at the same time the programme does provide access for students who would otherwise not be able to enter UCT.

The students on the Texts in the Humanities course have a wide range of language biographies. While all speak English (a high school English pass is a requirement for entry to UCT), there is a wide range of proficiency. For example, while many Coloured students would identify themselves as bilingual in English and Afrikaans, many black African students speak one or more African languages as their first language, in the home, and at their schools. Although English is the stated medium of instruction in South African schools from Grade 3 onwards, there is uneven implementation of this policy, with many teachers only speaking English as an additional language. Wealthy schools in urban suburbs tend to give the best access to English instruction, but there is still uneven wealth distribution and residential distribution of race groups in the country (as an ongoing effect of apartheid policies), which perpetuate inequality and benefit the white population. The students on the course, and at UCT in general, come from all over the country, although the majority come from the Western Cape and Cape Town and its suburbs specifically - other large universities exist in other provinces, but UCT does tend to attract the top students nationally because it is the highest-ranked university in Africa on a number of global ranking systems.

Texts in the Humanities is a course aimed at developing critical analysis and critical argument skills. The main aims of the course are to scaffold students in the critical analysis of academic texts, to develop critical argument, essay writing proficiency, and 
the relevant digital literacies for writing in the humanities. By the end of the course, students should be able to:

- Critically analyse a range of humanities texts including written and visual texts

- Understand and identify discourses

- Understand and identify genre features of academic and popular texts

- Conduct a critical discourse analysis

- Conduct a visual analysis

- Conduct a genre analysis

- Produce well-written and well-argued academic essays

The course was previously intended to scaffold students in critical analysis and argument specifically in English; however, as a direct challenge to English hegemony in the academy, in 2015 and 2016 the course began to incorporate texts in languages other than English, both the texts that are analysed, and the texts that students produce.

The pedagogic approach in the course includes concept glossaries, essays submitted in any language(s), translanguaging in lectures and tutorials, and translanguaging in online forums. This article provides a number of examples of these pedagogies, and considers the experience of the lecturers in teaching the course as well as the students' responses to these pedagogies. The lecturers are the two authors of this article (lecturer/ author 1 is also the convenor of the Texts in the Humanities course), so this is a partly ethnographic approach, in which reflections on the various learning activities were written by the two lecturers and subsequently analysed to unpack translanguaging practices and lecturers' perceptions of their efficacy. In addition, all formal lectures during the course were video recorded through the university's lecture recording system and the videos were subsequently reviewed in order to analyse translanguaging in classroom practice; tutorials were not recorded, so tutorial analysis primarily focuses on lecturer reflections and tasks described in the course outline. Online tasks are also reviewed and reflected on, including examples of students' online submissions; similarly with assessments, the tasks themselves, and student submissions were both analysed; additionally, student responses to these pedagogies are analysed by using the student course evaluations as data.

Data collection took place in 2015 when a limited number of translingual pedagogies were introduced (assignment 1 could be written in any language, and a multilingual glossary was undertaken), and 2016 when they were extended throughout the course pedagogies (including in lectures, tutorials, and all assignments and tasks). However, the data collection in 2016 was interrupted by large-scale student protests calling for decolonial education - so the course evaluation response rate in 2016 was much lower, due to the negative impact of protests on student participation in the course, and because face-to-face interaction with students was reduced to eight weeks rather than the standard 12 week semester, due to university closures in response to the protests. 
Table 1: Student participation in "Texts in the Humanities" 2015/2016

\begin{tabular}{|l|l|l|l|}
\hline Year & Number of students & $\begin{array}{l}\text { Assessments featuring } \\
\text { translanguaging }\end{array}$ & $\begin{array}{l}\text { Course evaluation } \\
\text { response rate }\end{array}$ \\
\hline 2015 & 83 & $\begin{array}{l}\text { Essay 1: Language } \\
\text { biography } \\
\text { Lab session: Discourse } \\
\text { glossary }\end{array}$ & $59 \%(49 / 83)$ \\
\hline 2016 & 86 & $\begin{array}{l}\text { Essay 1: Language } \\
\text { biography } \\
\text { Essay 2: Discourse } \\
\text { analysis } \\
\text { Essay 3: Video analysis } \\
\text { All lab sessions }\end{array}$ & $23 \%(20 / 86)$ \\
\hline
\end{tabular}

\section{LECTURERS' LANGUAGE BIOGRAPHIES}

The two lecturers on the course come from significantly different cultural and linguistic backgrounds. In the second lecture of the course, the two lecturers presented their own language biographies, partly as a demonstration of how to write essay 1, and partly as an orientation to the multilingual focus of the course.

Lecturer 1, who is also the course convenor and corresponding author of this article, was born in the UK and moved to South Africa in 2005. She speaks a number of mainly European languages to varying proficiencies, including Dutch, which gives her some access to Afrikaans (written). She has done two courses in basic isiXhosa, and has worked with both isiXhosa and isiZulu in her sociolinguistics research on "tsotsitaal."4 However, in the spoken mode, she is reliant on English.

Lecturer 2 was born in South Africa. His home language is siSwati, which is closely related to isiZulu, isiXhosa and isiNdebele, all being languages from the Nguni group. He comes from Mpumalanga, the province in South Africa in which siSwati is most prevalent. He moved to Johannesburg with his family when he was young, and was exposed to the mix of languages in multilingual Johannesburg, particularly isiZulu and seSotho, and "tsotsitaal" (see footnote 4). He also spent some time in a xiTsonga school. As a result of this background he speaks all the South African official languages to some degree, other than Venda.

4 Tsotsitaal usually refers to a register of speaking the urban vernacular (Mesthrie and Hurst 2013) but is often used colloquially to refer to the language mix found in highly multilingual centres such as Johannesburg (Makelela 2013). 


\section{DATA ANALYSIS}

The data will be presented according to pedagogical modality: lectures, tutorials, online learning, and assignments, followed by an overview of student responses to the pedagogies.

\section{Lectures}

The course takes an explicit multilingual orientation. For example, in the first lecture for the course, presented by lecturer 1, English was problematised as the dominant language of the humanities in South Africa. The lecturer discussed English as the medium of the institution, for texts both received and produced, and introduced the multilingual focus of the course:

So we are trying to get away from this very strict academic English rule that you come across everywhere else in the university. (Lecturer 1, lecture 1, 2016)

The lecturer also introduced Frantz Fanon and Ngugi wa Thing'o and their views on the "colonisation of the mind" through language.

Lecture 1 was followed up by a "translanguaging" presentation in lecture 2 which explained to students the motivation behind the multilingual pedagogies in the course. This presentation introduced students to the notion of the monolingual norm, and encouraged thinking about Africa as a multilingual continent and the idea of the monolingual norm as a fiction. This involved challenging the dominance of English in the South African academy as well as challenging English as the only language needed in the world of work and highlighting multilingualism in South African employment sectors. The lecturer also challenged the notion of language purity and fixed standard versions of English and other languages. The lecturer introduced multilingualism as a valid language for teaching and learning, and the course emphasis on translanguagingsuch that, within one essay or text, students can pull in resources from different languages, styles, dialects etc. This introduction to the course in lectures 1 and 2 was intended to set the scene for a number of translanguaging tasks and assessment throughout the course.

\section{Language of Lecturers}

Throughout the course lectures, lecturer 1 almost exclusively spoke to the students in English. For example, even though lecture 1 offers a critique of monolingualism, it was presented in English. During the second lecture, in which the two lecturers demonstrated their own language biographies as a model for the first assignment, lecturer 1 included some small transitions into other languages, including Hebrew, Spanish and isiXhosa as in the following example: 
I can understand a little bit of tsotsitaal ... I can read it a bit as well because it's sort of mixed language, takes from Afrikaans, takes from isiXhosa, takes from all sorts of places - and I've done a couple of courses in isiXhosa—ndi thetha isiXhosa kancinci ["I speak a little isiXhosa"] [students laugh in response] — and I can read it a little bit, and I can understand a lot of written Afrikaans, because of my Dutch and German before, they're very closely related. (Lecturer 1, lecture 2)

Primarily though, she used English language in lectures. She did however explain her strategy to incorporate other languages in lecture examples:

Because of my lack of fluency in languages other than English, I was constrained in speech, and relied on Msakha to speak in other languages; but when giving examples on the board and in PowerPoint slides I tried to use other languages. (Lecturer 1, reflection)

Lecturer 2 on the other hand often used African languages and Afrikaans in his lectures. He also used informal (youth) varieties, specifically the variety commonly referred to as tsotsitaal in the literature (cf. Mesthrie and Hurst 2013). For example, in the second lecture when he modelled his own language biography, he began by greeting the room using the tsotsitaal word eita (/heita "greetings"), which immediately elicited a response from a number of students in the room:

Lecturer 2: Is this thing on? Eita, nigrand? [“How are you (all)? Are you well?”]

Students: Moja, kanjan?

Lecturer 2: Moja, moja .

Moja is a tsotsitaal response greeting meaning "fine." The lecturer then switched into Afrikaans:

Hoe gaan dit met u mense? [“How goes it with you people?"] (Lecturer 2, lecture 2)

His Afrikaans response elicited further responses from the students. He clarified his Afrikaans proficiency (to some extent reproducing an ideology of language standards) by saying:

Hey, okay. Now I'm gonna have problems cause beng' zo zama ukushaya isiZulu-nyana, le SeSotho-nyana, and a bikie Afrikaans, maar my Afrikaans is nie dar die lekker, maar ek prober. ["Hey okay. Now I'm gonna have problems because I can do isiZulu and seSotho and a little Afrikaans, but my Afrikaans is not very good, but I'll try”] (Lecturer 2, lecture 2)

The lecturer then took on the role of Imbongi and did Izibongo: a particular style of speaking which is a Nguni way of introducing someone (including yourself) that the speaker is proud of or wants to thank. In this case, the lecturer recited his clan names. These clan names are used to identify people in terms of tribe, language, geography and even bloodline. 
Okay, ligama lami nguMsakha, s'bongo nguMona, Mashahane lowashay' inyoka wayibek' endleleni, watsi labanye batawu ndlula bayidobhe. (Lecturer 2, lecture 2)

Following this statement, the students screamed and clapped in approval. Whereas in the classroom this style might be seen as informal, in other indigenous settings this style is in fact formal (for example during initiations, weddings, and inaugurations). Both the language and the cultural reference of the speaking style clearly resonated with a large segment of students in the lecture theatre.

From there, the lecturer moved mainly into English, but included translanguaging features in his speech, simultaneously translating for English-speaking students:

... you go to your home language, but unfortunately besingekho siSwati-there was no Swati there. (Lecturer 2, lecture 2)

When he talked about his school experience, he highlighted the strange dislocation between the content (Shakespeare) and his own home language, as well as the diminishing effect that English as the academic language has on his home language:

When they talk about sonnet I'm like "yini i-sonnet," because where I come from we didn't do u-Shakespeare, we learned stories in my home language. So sometimes I wonder if my home language - "home" as in me, the body, I wonder if my home language is still the language in which I was born, because I don't use it here. (Lecturer 2, lecture 2)

Arguably, both the common experiences from a similar, multilingual, African language background, as well as the use of African languages themselves, gave African languagespeaking students validation of their experiences (coming from a lecturer) - and of their languages (used by a lecturer) that they don't get elsewhere in the university.

The lecturer reflects that

In my lecture sessions I have found that students are eager and excited to participate. I would tell them that "today you will do the talking ..." and indeed I find that they freely participate. (Lecturer 2, reflection)

Importantly, the students who participated in his sessions are those who were usually silenced. While speaking in English as a second language speaker can be intimidating in a large class, when the language medium is switched, suddenly students who speak African languages are empowered, as their linguistic resources become valued.

Lecturer 2 points out that English remains the main language of the lecture theatre, but translanguaging allows other elements of students' repertoires to enter classroom discourse:

Although I encourage students to use their home languages when making comments or asking questions in class, English remains the main language. However, in their usage of English, I can hear that the English is not expressed in [only] English, in that a student will use a phrase such as ilentuza ["what-you-call-it" (a phrase used when you forget a specific word)] while delivering 
a sentence in "English." Students have therefore taken ownership of the language process in the classroom. (Lecturer 2, reflection)

\section{Language of Lecture Examples and PowerPoints}

In lecture presentations, English remained the dominant language of explanation, but other languages were drawn on quite extensively for examples. For instance, in lecture 3, the students were introduced to the "World of Texts" and asked to expand their understanding of what might be considered a "text." Examples given included the following:

- Nsibidi writing system from Southern Nigeria

- A South African stamp from 1947 with text in Afrikaans

- An English advertisement from the South African energy company Eskom

- An advertisement by the food company Nandos with text in colloquial Afrikaans

- A street sign in isiXhosa

- Road signs from Israel in Arabic, Hebrew and English

- The "Lord's Prayer" in tsotsitaal

This model was followed in other lectures, such as a lecture that focused on musical texts by using examples of struggle songs in isiXhosa and isiZulu, a lecture on the bible as a text with examples of Hebrew, Aramaic, English and isiXhosa biblical text, and a lecture on symbols including examples from Arabic and emoticons.

However, lectures that introduced theoretical concepts (such as lectures on "discourse" and "genre") tended to exclusively use English for concept explanation. Therefore as the course progressed and engaged more with theory, the multilingual focus of lectures fell away.

\section{TUTORIAL EXPERIENCES}

Tutorials are small group classes (on average 15 students per tutorial) that are run by a lecturer or postgraduate assistant (tutor), and which are intended to enable in-depth discussion and group work on concepts covered in the lectures. Similarly to the lectures, lecturer 1 exclusively spoke English in her tutorial sessions, although tutorial tasks and assignments were used to encourage students to write in other languages, and discussion questions were posed which encouraged students to challenge English dominance in the academy. For example, in week 2, one of the tutorial discussion points relating to the writing of Frantz Fanon was: "Is it okay to adopt a colonial language in order to access global resources?" 
Lecturer 2 used more translanguaging with his tutorial group, although he describes English as the "base language" for this classroom interaction:

The tutorial, which is made up of 15 students, is what I call a safe space for students. Students in the class know they can be who they are in terms of expression. While English still remains the base language, students still mix it with their mother tongues. (Lecturer 2, reflection)

Outside the classroom, he reports that students often spoke to him in their home languages; so the tutorial space is perhaps still constrained by the need for a common language of communication, as well as by the English framing of concepts and theories.

As students are able to choose which tutorial they sign up for, it would be interesting in future to unpack whether language plays a role in tutor choice. For example, a slight majority of students in lecturer 1's tutorial group were bilingual English-Afrikaans speakers and first language English, while in lecturer 2's tutorial a majority were African language speakers. Providing a range of language options for tutor groups by employing multilingual tutors is very important both for classroom pedagogy and for marking (see assignments section below).

\section{ONLINE LEARNING (TASKS AND STUDENT MULTILINGUAL SUBMISSIONS)}

Online learning in the course revolved around weekly computer lab sessions, which ran for one to two hours, when students would complete tasks using an online course platform. Most online learning tasks involved reading a text and/or doing some kind of analysis (discourse, genre or visual analysis) and then commenting either in a quiz format, or in a forum in which all students contributed and were able to see and respond to each other's contributions. Forum and quiz submissions were allowed in any language.

The task instructions and questions were posed in English, and the predominant language that students responded in was English, but some students did take advantage of the option to respond in another language. For example, in week 2, students were asked to comment on Fanon's work in response to the following prompt:

Fanon says, "To speak a language ... means above all to assume a culture, to support the weight of a civilization." Do you think this is a good or a bad thing? Give examples of why it might be a good/bad thing. Write 1 comment of your own, \& reply to another. (Lab week 2, task 1)

While responses were predominantly in English, the following examples were from students who used translanguaging or preferred to respond in their home language:

ukuthetha ulwimi olungelolwakho ["speaking a language that is not your own"] does not mean you have changed as a person, you can speak multiple languages and only have one culture, basically, a language is only a tool of communication between two people for mutual understanding. 
Ek dink dat dit ' $n$ goeie ding is. Deur ' $n$ taal te praat neem ' $n$ mens daardie taal se spesifieke erfenis aan en ' $n$ mens beleef jou lewe en daaglikse ervaarings deur daardie taal. ["I think it's a good thing. By learning to speak a language a person experiences that language's specific heritage and human life and daily experiences in that language."]

Some tasks also included texts in languages other than English, and a number of online learning tasks encouraged students to interrogate the monolingual norm. For example, in the second computer lab session (week 3 of the course), students were asked to watch an interview with Ngugi wa Thiong'o in which he argued that English is not an African language, and then students were asked to read his article "Tongue and Pen: A Challenge to Philosophers from Africa/ Rũrĩmĩ na karamu: ithoga harĩ athamaki a Abirika" in which he argues that African philosophy should be written in African languages. The text was provided in both English and the original Gikuyu.

Further on in the course, in week 4, students were asked to start to engage with the concept of discourse, in order for them to be able to conduct discourse analysis on texts in the humanities disciplines. An online task was developed for them to start to engage with a number of definitions of discourse, provided to them in lectures and in online materials. In the relevant lab session, they were first asked to watch a video on discourse ("what is discourse analysis?"), and then to enter their definition of discourse in a forum discussion, in their home language. The task also asked them to engage with other students' definitions in the forum:

Having watched the video above, follow the link below to the Forum Discussion, where you will write your definition of discourse in your first language, or your home language, and then comment on someone else's definition. (Lab week 4, task 2)

Following the forum discussion, the students were asked to upload their definition of discourse in both English and their home language. The use of translingual concept glossaries has been explored by authors such as Madiba (2014) who suggests that this work of translating can extend students' understanding of complex concepts. Some examples from the forum discussion are as follows:

Discourse is the communication of thought by words. It is also a social boundary defining what can be said about a specific topic. Diskoers is om te praat. ["Discourse is to speak." (Afrikaans)]

Intetho ekhethekileyo (Discourse), yindlela yokuthetha, ukubhala nokwabelana ngolwazi eyohluka ngokwengingqi, ngokwo luntu, nangokweezifundo loo ntetho isuka kuzo. ["Discourse is a way of talking and writing and sharing knowledge that differs based on community, culture and even the education where the discussion stems from." (isiXhosa)]

Including instructions in other languages, and reiterating the option to respond in other languages, may further encourage translingual and multilingual activity in these online spaces. There is also a great opportunity to introduce more texts for analysis in languages other than English as part of the online tasks. 


\section{Assignments (Multilingual Submissions)}

Throughout the course we reiterated that students were allowed to submit their assignments in any language they preferred. This was introduced during the first lecture and reiterated throughout the course, including in the course outline in the assignment instructions:

You can write this essay in any language you like. You can switch between languages as you write-you can write one word, or sentence or paragraph in Tswana, another in English, another in Zulu, or write the whole essay in Sotho, or write the whole essay in English, whatever you prefer. (Texts in the Humanities course outline, 2016)

Students did take the opportunity both in 2015 and 2016 to write their entire language biography essay in their home language, or to mix between languages within their essay:

[I am] an almost twenty year old Swazi girl who is infused with so many lingos, but can only praat drie tale ["speak three languages" (Afrikaans)]. Both of my names and surname are siSwati, but also, they are a part of the Nguni Language. This means that I can understand other Nguni languages and converse with them without great difficulty. Therefore, people often mistake me for Xhosa, Zulu or even Tswana. I was born and raised in the Land of emaSwati [ema is the plural modifier of Swati, so the literal translation is "land of the Swatis"] by my very two eccentric great grandparents who valued both culture and education above all things. Manje-ke ngikhule ngidla tonkhe tinhlobo tetibhidvo, inyama, lipalishi,umbhonyo, ematsanga naloyongeke uze uwatfole kuletinye tindzawo ngaphandle kwase khaya, kanye nalokunye kudla lokudliwa ngemaSwati. ["So then, I grew up eating spinaches, meat, pap, peanuts, pumpkins/ butternuts and that ngeke. You will not find them anywhere else except home ... and any other foods that Swatis eat." (siSwati)] (Student, language biography assignment 2015)

In this example, the student writes in "very deep Swati" (lecturer 2). The student makes the switch into siSwati when she is referring to a number of foods which are only available within her cultural background, some of which have no direct English language equivalent. For example, Tibhidvo (translated as "spinaches") are the leaves of various plants such as the pumpkin plant, while Ngeke refers to a mixture of pap (a traditional porridge made from ground maize), water and sugar, often eaten in disadvantaged communities because of its low cost.

An example from isiXhosa follows:

My language is a perfect reflection of who I am, my language my image. Ndingumxhosa ndithetha isiXhosa kwaye ndiyazingca ngelwimi lwam lwakwantu. ["I speak isiXhosa and Sesotho and I am proud of my (indigenous) language."] This paper will conduct a study of how language had an impact on me hence I am this person I am today. Esixhoseni we usually say umntu ngumntu ngabanye abantu, Mna ndithi Umntu ngumntu ngelwimi lwakhe. ["As Xhosas we usually say a person is a person through other people; I say, a person is a person through her/his language."] (Student, language biography assignment 2015) 
In this example, the student takes a well-known Xhosa proverb and reapplies it to their essay argument. Again the inclusion of translanguaging enables this student to make meaning across and between different language resources and to draw on cultural knowledge and resources.

Both lecturers noted students' willingness to use other languages in their writing, and their own language repertoires and resources enabled them to engage with these multilingual texts:

A number of students in my tutorial groups submitted essays which included other languages/ translanguaging/ code-switching. If I didn't understand, I used Google Translate which I was happy to discover now has the capacity to translate isiXhosa. (Lecturer 1, reflection)

As the course progressed, students used translanguaging and other languages less in assignment submissions. This might be because it becomes harder to write assignments in other languages when the concepts are learned through English in the classroom. In 2016, only a few students submitted essays for the second and third assignments that featured translanguaging, and in those cases the translanguaging was minimal. For example, one student makes the switch into Afrikaans when referring to herself in the first person plural ("we as Afrikaners"). Another student switches into isiXhosa only at the very end of their essay, when concluding; in this case, the student appears to struggle to summarise their argument in English, and draws on isiXhosa mixed with English to fully explain their point.

In general, the option to submit assignments in any language or mix of languages was one of the most well received and easiest to implement pedagogies within the course, as evidenced in the course evaluations.

\section{Student Responses to Translanguaging Pedagogies}

In the course evaluation in both 2015 and 2016, students in general appreciated the opportunity to use other languages in the course. In response to a question regarding what they appreciate about the course, a number of students highlighted the submission of essays in any language as something they appreciated. Students particularly appreciated how translanguaging pedagogies made them feel that their other languages and language resources were being valued:

By using my home language, it encouraged me to feel more comfortable with my writing, and valued by knowing that my language is also of importance. (Course evaluation 2016)

Yes, I really did find it encouraging for the lecturers to allow the students to write in their language that means they are accepting of all languages and cultures. (Course evaluation 2015)

Yes, encouraging the use of different languages allowed diversity in the course and was a very interesting initiative because it showed that our languages were being recognised and are appreciated. (Course evaluation 2015) 
Despite the lack of practical take-up of the multilingual submission option after essay 1 , students continued to appreciate the option. This perceived recognition and valuing of all languages relates to issues around social justice, particularly in terms of justice for recognition - putting a focus on socio-cultural groups who are struggling to "defend their identities, end cultural domination and win recognition" (Cumming-Potvin 2009, 84). In the South African higher education context this can be read as a response to the colonial wound, and therefore as a decolonial pedagogic move. In 2016 in the evaluation, students were asked, in relation to the ongoing protests for decolonised education, whether they had any "suggestions for how we can decolonise the syllabus, materials and assessments of this course." In response, students pointed to the multilingualism as one aspect of the course which responded to calls for decolonisation:

I feel there is no need to decolonize the syllabus as we are freely able to write our essays and speak in the language we are comfortable in. (Course evaluation 2016)

The pedagogies used in this course may ultimately lead to increased engagement by students, as reported by this student:

The idea of writing our personal language history essays with our home languages, was more than valuable. I was more engaged. (Course evaluation 2015)

However, in 2015 some students did report some negative effects, particularly in terms of how translanguaging in this course interfaces with the university language policy and practice in other departments:

It was fun to use other languages but created a struggle for my other courses as I reverted to the other language more often than english and I had to redo my thoughts as UCT's language policy requires English only in submitted work. (Course evaluation 2015)

In an English University I expect to write all my assignments in English. (Course evaluation 2015)

\section{SUMMARY AND CONCLUSIONS}

Results of the introduction of translanguaging pedagogies suggest positive responses overall to the approach. Students found their languages valued and legitimised within the academic space; they were no longer silenced or considered inferior; and lecturer 2 experienced a flattening of the usual hierarchy in classes due to students having linguistic and conceptual knowledge that could extend discussions and theories. In particular, the pedagogy seems to benefit those students who are usually the most disadvantaged, students from rural or township backgrounds who find the (Eurocentric) institutional culture and language most alienating. This demographic is also the student group most closely and actively involved in protests such as Rhodes Must Fall and the call for a decolonised curriculum, so the pedagogies described here are in fact responding to this 
call, which is a social justice issue. The benefit might also be partly as a result of more culturally relevant content, which is also a consideration in the course syllabus. For example, lecturer 2 recollects that rural and township students were more involved in discussions about kwaito music, and the symbolic meanings of blackness, darkness and shadow within their cultural contexts.

In terms of social justice, it is becoming clear that in the South African higher education context, teaching and assessment strategies are not fair for those students who do not speak English as their first language (Hurst 2016) and that new pedagogical practices, as well as policies, need to be implemented if we are to truly move towards decolonisation of the academy. One of the most critical, and usually avoided, interfaces is language; to create not only a multilingual academic staff, but also multilingual courses and materials, seems like a huge if not impossible task. However, as this course demonstrates, it is possible to apply translanguaging techniques with relatively little additional resources, given a creative and flexible staff. Related to this, current calls for decolonisation include the imperative to transform the academic staff profile to better reflect the demographics of South Africa (Breetzke and Hedding 2016), which could further enable translanguaging pedagogies.

Ultimately, it is the responsibility of South African higher education to respond to this imperative; students within a socially just pedagogic framework should not be impacted negatively by "discrimination through sex, language, culture, ethnicity, religion or disability (or socio-economic status and geographic location)" (CummingPotvin 2009, 84). Unfortunately, English currently discriminates in many ways, and often against the very students that South African education policy is currently aiming to prioritise. It is clearly unjust to require indigenous speakers to adopt a foreign language at the expense of their own language resources; a pedagogy of translanguaging is both a practical and ethical response to the current climate in South African higher education.

However, the achievement of a true translanguaging pedagogy requires further work, for example to combat the tendency to fall back on English language in the choice of theoretical texts, when discussing abstract and academic concepts and in more complex assessment tasks. English language speaking students also need to be sensitised to the multilingualism of the broader society and the relevance of other languages in the world of industry and government.

\section{REFERENCES}

Adhikari, M. 2005. Not White Enough, Not Black Enough: Racial Identity in the South African Coloured Community. Cape Town: Double Storey Books.

Babaci-Wilhite, Z. 2012. "A Human Rights-Based Approach to Zanzibar's Language-in-Education Policy.” World Studies in Education 13 (2): 17-33. https://doi.org/10.7459/wse/13.2.03 
Babaci-Wilhite, Z. 2013. "Local Languages of Instruction as a Right to Education for Sustainable Development." Sustainability 5 (5): 1994-2207. https://doi.org/10.3390/su5051994

Babaci-Wilhite, Z., and M. A. Geo-JaJa. 2011. “A Critique and Rethink of Modern Education in Africa's Development in the 21st Century." Papers in Education and Development (PED). Journal of the School of Education 30: 133-54.

Blommaert, J., and B. Rampton. 2011. "Language and Superdiversity.” Diversities 13 (2): 1-21.

Bostad, I. 2012. "Existential Education and the Quest for a New Humanism: How to Create Disturbances and Deeper Thinking in Schools and Universities?" In Enlightenment, Creativity and Education, edited by L. Wikander, C. Gustafsson and U. Riis, 45-59. Rotterdam: Sense Publishers. https://doi. org/10.1007/978-94-6209-052-1_3

Breetzke, G., and D. Hedding. 2016. "The Changing Racial Profile of Academic Staff at South African Higher Education Institutions (HEIs), 2005-2013.” Africa Education Review 13 (2): 147-64. https:// doi.org/10.1080/18146627.2016.1224114

Breidlid, A. 2013. Education, Indigenous Knowledges and Development in the Global South. New York: Routledge.

Canagarajah, S. 2011. "Codemeshing in Academic Writing: Identifying Teachable Strategies of Translanguaging." The Modern Language Journal 95 (3): 401-17. https://doi.org/10.1111/j.15404781.2011.01207.x

Canagarajah, S. 2013. Translingual Practice: Global Englishes and Cosmopolitan Relations. New York: Routledge.

Cumming-Potvin, W. 2009. "Social Justice, Pedagogy and Multiliteracies: Developing Communities of Practice for Teacher Education." Australian Journal of Teacher Education 34 (3). https://doi. org/10.14221/ajte.2009v34n3.4

Fanon, F. 1952. Black Skin, White Masks. Translated by C. L. Markmann. New York: Grove Press.

Fraser, N. 1997. Justice Interruptus: Critical Reflections on the "Postsocialist" Condition. New York: Routledge.

Garuba, H. 2015. "What Is an African Curriculum?” Mail \& Guardian, April 17. http://mg.co.za/ article/2015-04-17-what-is-an-african-curriculum/ (accessed December 13, 2017).

Gibson, N. 2011. Living Fanon: Global Perspectives. New York: Palgrave Macmillan. https://doi. org/10.1057/9780230119994

Gyagenda, I., and W. Rajab-Gyagenda. 2014. "Examining Ugandan and Malawian Language of Instruction Policies from a Linguistic Human Rights Perspective: Past and Present Challenges and Realities." In Giving Space to African Voices: Rights in Local Languages and Local Curriculum, edited by Z. Babaci-Wilhite, 149-62. Rotterdam: Sense Publishers. https://doi.org/10.1007/978-94-6209-734-6_9

Heller, M., ed. 2007. Bilingualism: A Social Approach. Basingstoke: Palgrave. https://doi. org/10.1057/9780230596047 
Hurst, E. 2016. "Navigating Language: Strategies, Transitions, and the 'Colonial Wound' in South African Education." Language and Education 30 (3): 219-34. https://doi.org/10.1080/09500782.2015.1102 274

Kerner, I. 2014. "Countering the Legacies of Colonial Racism: Decolonial and Postcolonial Approaches." In Postcoloniality -Decoloniality—Black Critique: Joints and Fissures, edited by S. Broeck and C. Junker, 145-58. Frankfurt: Campus Verlag.

Madiba, M. 2014. "Promoting Concept Literacy through Multilingual Glossaries: A Translanguaging Approach." In Multilingual Universities in South Africa: Reflecting Society in Higher Education, edited by L. Hibbert and C. van der Walt, 68-87. Bristol: Multilingual Matters.

Mahapa, R. 2014. “UCT Admission Policy: An Open Letter to the Vice Chancellor Dr Max Price.” News24, May 28. http://voices.news24.com/ramabina-mahapa/2014/05/uct-admission-policy-open-lettervice-chancellor-dr-max-price-2/ (accessed December 13, 2016).

Makalela, L. 2013. "Translanguaging in Kasi-Taal: Rethinking Old Language Boundaries for New Language Planning." Stellenbosch Papers in Linguistics Plus 42: 111-25. https://doi.org/10.5842/42-0-164

Makalela, L. 2015. "Translanguaging as a Vehicle for Epistemic Access: Cases for Reading Comprehension and Multilingual Interactions." Per Linguam 31 (1): 15-29. https://doi.org/10.5785/31-1-628

Makoni, S., and A. Pennycook. 2005. "Disinventing and (Re)Constituting Languages." Critical Inquiry in Language Studies 2 (3): 137-56. https://doi.org/10.1207/s15427595cils0203_1

McKinney, C. 2017. Language and Power in Post-Colonial Schooling: Ideologies in Practice. London: Routledge.

Mesthrie, R., and E. Hurst. 2013. "Slang Registers, Code-Switching and Restructured Urban Varieties in South Africa: An Analytic Overview of Tsotsitaals with Special Reference to the Cape Town Variety." Journal of Pidgin and Creole Languages 28 (1): 103-30. https://doi.org/10.1075/jpcl.28.1.04mes

Mignolo, W. 2005. The Idea of Latin America. Malden: Blackwell.

Mignolo, W. 2009. "Coloniality: The Darker Side of Modernity." In Contemporary Artists Researching Modernity and Modernism, edited by S. Breitwisser, 39-49. Barcelona: Catalog of the Exhibit at the Museum of Modern Art.

North, C. 2006. "More Than Words? Delving into the Substantive Meaning(s) of 'Social Justice'in Education." Review of Educational Research 76 (4): 507-36. https://doi.org/10.3102/00346543076004507

Prah, K. 1999. “African Renaissance or Warlordism?” In African Renaissance: The New Struggle, edited by M. Makgoba, 37-61. Sandton: Mafube.

Skutnabb-Kangas, T. 1994. "Linguistic Human Rights: A Perspective for Bilingualism.” In Bilingualism in Deaf Education, edited by I. Ahlgren and K. Hyltenstam. Hamburg: Signum.

Skutnabb-Kangas, T. 2000. Linguistic Genocide in Education or Worldwide Diversity and Human Rights? Mahwah: Lawrence Erlbaum Associates. 
Sure, K., and N. Ogechi. 2009. Linguistic Human Rights and Language Policy in the Kenyan Education System. Addis Ababa: Organisation for Social Science Research in Eastern and Southern Africa.

Williams, C. 1994. “Arfarniad o Ddulliau Dysgu ac Addysgu yng Nghyd-destun Addysg Uwchradd Ddwyieithog" [An Evaluation of Teaching and Learning Methods in the Context of Bilingual Secondary Education]. PhD dissertation, University of Wales. 